\title{
Salinactinospora qingdaonensis gen. nov., sp. nov., a halophilic actinomycete isolated from a salt pond
}

Correspondence

Xiao-Hua Zhang

xhzhang@ouc.edu.cn

\author{
Xianbo Chang, ${ }^{1,2}$ Wenzheng Liu ${ }^{1}$ and Xiao-Hua Zhang ${ }^{1}$ \\ ${ }^{1}$ College of Marine Life Sciences, Ocean University of China, Qingdao, PR China \\ ${ }^{2}$ College of Environmental \& Material Engineering, Yantai University, Yantai, PR China
}

The family Nocardiopsaceae was created, with Nocardiopsis as the type genus, by Rainey et al. (1996) based on data obtained using a polyphasic taxonomic approach. At present, the family Nocardiopsaceae contains seven genera, namely, Nocardiopsis (Meyer, 1976), Thermobifida (Zhang et al., 1998), Streptomonospora (Cui et al., 2001), Haloactinospora (Tang et al., 2008), Marinactinospora (Tian et al., 2009), Murinocardiopsis (Kämpfer et al., 2010) and Spinactinospora (Chang et al., 2011). With more than 25 species and subspecies, the genus Nocardiopsis is the largest genus in the family Nocardiopsaceae. Most strains of the genus Nocardiopsis were isolated from hypersaline soils (M.-G. Li et al., 2003; W.-J. Li et al., 2004, 2006; Chen et al., 2008; Yang et al., 2008) and some strains were isolated from marine sediments (Sabry et al., 2004; Kroppenstedt \& Evtushenko, 2006; Tian et al., 2009). The four species of the genus Thermobifida were isolated from composts or

Abbreviations: DPG, diphosphatidylglycerol; ISP, International Streptomyces Project; PC, phosphatidylcholine; PI, phosphatidylinositol; PIM, phosphatidylinositol mannoside; PME, phosphatidylmethylethanolamine.

The GenBank/EMBL/DDBJ accession number for the 16S rRNA gene sequence of strain CXB832 ${ }^{\top}$ is GU253338.

Supplementary figures and a sequence alignment are available with the online version of this paper. damp stored hay (Zhang et al., 1998), manure heaps (Kukolya et al., 2002) and a salt mine (Yang et al., 2008). The five species of the genus Streptomonospora were isolated from a salt lake (Cui et al., 2001; Cai et al., 2009) and soil (W.-J. Li et al., 2003; Cai et al., 2008). The genera Haloactinospora, Marinactinospora and Spinactinospora contain only one species and the type species of these genera were isolated from a salt lake (Tang et al., 2008) and marine sediments (Tian et al., 2009; Chang et al., 2011). Many strains of the family Nocardiopsis have been isolated from saline soils and are halophilic, some of which are strictly halophilic (Tang et al., 2008). A novel strain was isolated from a salt pond in Qingdao, China, designated CXB832 $2^{\mathrm{T}}$, and was found to be phylogenetically closely related to members of the genera Nocardiopsis and Haloactinospora. In the present study, the taxonomic position of strain CXB832 ${ }^{\mathrm{T}}$ was determined by using a polyphasic taxonomic approach.

Strain $\mathrm{CXB} 832^{\mathrm{T}}$ was isolated and maintained on starchcasein agar medium ( $\mathrm{pH} 7.5)$ supplemented with $15 \%(\mathrm{w} / \mathrm{v})$ $\mathrm{NaCl}$ at $37{ }^{\circ} \mathrm{C}$ for 3 weeks. The composition of the starchcasein agar medium was (distilled water $\mathrm{l}^{-1}$ ): $10 \mathrm{~g}$ starch, $0.3 \mathrm{~g}$ casein, $2 \mathrm{~g} \mathrm{KNO}_{3}, 0.05 \mathrm{~g} \mathrm{MgSO}_{4} .7 \mathrm{H}_{2} \mathrm{O}, 2 \mathrm{~g} \mathrm{~K}_{2} \mathrm{HPO}_{4}$, $0.02 \mathrm{~g} \mathrm{CaCO}_{3}, 0.01 \mathrm{~g} \mathrm{FeSO}_{4}$ and $15 \mathrm{~g}$ agar. After primary isolation and purification by the streak plate method, the isolates were preserved both on slants of International 
Streptomyces Project medium 4 agar (ISP 4; Shirling \& Gottlieb, 1966) supplemented with $10 \%(\mathrm{w} / \mathrm{v}) \mathrm{NaCl}$ at $4{ }^{\circ} \mathrm{C}$ and in $20 \%(\mathrm{v} / \mathrm{v})$ glycerol at $-80{ }^{\circ} \mathrm{C}$.

All the media were supplemented with $10 \%(\mathrm{w} / \mathrm{v}) \mathrm{NaCl}$ for the observation of growth. Strain $\mathrm{CXB} 832^{\mathrm{T}}$ grew well on ISP 2, ISP 3, ISP 4 and ISP 5 agars (Shirling \& Gottlieb, 1966), Czapek solution agar (Waksman, 1961), nutrient agar (Difco) and potato agar (Waksman, 1961). The novel strain did not produce diffusible pigments on any of the media tested. Micromorphology was observed by light microscopy (BH 2; Olympus) and scanning electron microscopy (JSM5600LV; JEOL) using cells incubated for $7,14,21$ and 28 days on ISP 2 agar supplemented with $10 \%(\mathrm{w} / \mathrm{v}) \mathrm{NaCl}$. The colours of the substrate and aerial mycelia were determined by comparison with chips from the ISCC-NBS colour charts (Kelly, 1964). The aerial and substrate mycelia were well developed on most media tested, producing a pale yellow to deep yellow substrate mycelium that carried white aerial hyphae on ISP 4 agar supplemented with $10 \%(\mathrm{w} / \mathrm{v}) \mathrm{NaCl}$. The aerial mycelium formed long chains of spores at maturity that were rodshaped with smooth surfaces; they were non-motile (Fig. 1a, b). Substrate mycelium was extensively branched with non-fragmenting hyphae (Fig. 1c).

Physiological characteristics, including temperature and $\mathrm{pH}$ ranges for growth and tolerance to $\mathrm{NaCl}$, were tested using ISP 4 as the basal medium. Growth was tested at $4,16,20$, $28,37,40,43,46,49,50,51$ and $52{ }^{\circ} \mathrm{C}$ on ISP 4 agar with $10 \%(\mathrm{w} / \mathrm{v}) \mathrm{NaCl}$. For tolerance experiments involving concentrations of $\mathrm{NaCl}$ between 0 and $25 \%$ (at intervals of $1 \%)$, ISP 4 was used as the basal medium. The $\mathrm{pH}$ range for growth was investigated between $\mathrm{pH} 4.0$ and 11.0 at intervals of $1.0 \mathrm{pH}$ unit using the buffer system described by $\mathrm{Xu}$ et al. (2005). Carbon-source utilization for growth was performed as described by Shirling \& Gottlieb (1966). Tests for hydrolysis of cellulose, gelatin, starch and Tweens 20, 40, 60 and 80, nitrate reduction, utilization of urea, milk coagulation and peptonization and production of $\mathrm{H}_{2} \mathrm{~S}$ and melanin were performed with $10 \%(\mathrm{w} / \mathrm{v}) \mathrm{NaCl}$ as described by Gonzalez et al. (1978). Antibiotic susceptibility was examined according to Groth et al. (2004) using antibiotic discs on ISP 4 agar with $10 \%(\mathrm{w} / \mathrm{v}) \mathrm{NaCl}$. Haloactinospora alba DSM $45015^{\mathrm{T}}$ (the type species of the genus Haloactinospora) obtained from the DSMZ (Deutsche Sammlung von Mikroorganismen und Zellkulturen $\mathrm{GmbH}$, Braunschweig, Germany) was used as a reference strain and cultured under the same conditions. The detailed physiological properties of the novel strain are given in the genus and species description (see below) and are presented in Table 1.

Biomass for chemotaxonomic studies was obtained by centrifugation after cultivation in ISP 4 broth with $10 \%$ $(\mathrm{w} / \mathrm{v}) \mathrm{NaCl}$ for 7 days at 180 r.p.m. at $37^{\circ} \mathrm{C}$. For fatty acid analyses, cells were grown on tryptic soy agar (Difco) containing $10 \%(\mathrm{w} / \mathrm{v}) \mathrm{NaCl}$ at 180 r.p.m. at $37^{\circ} \mathrm{C}$. For analysis of amino acids and sugars in the cell-wall
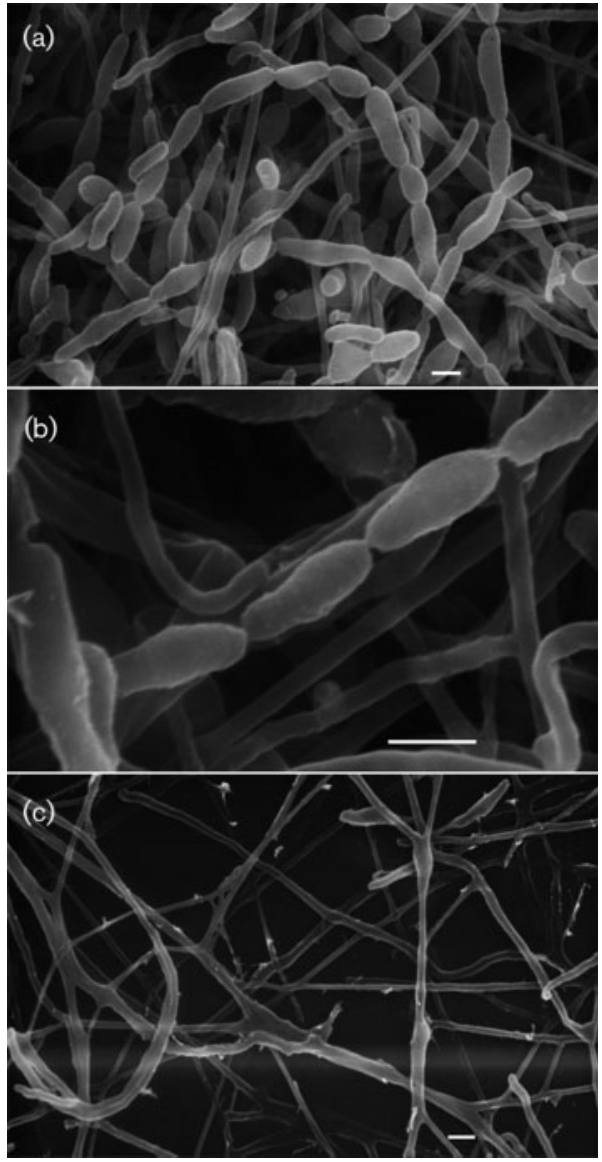

Fig. 1. Scanning electron micrographs showing the long spore chains and spores of strain $\mathrm{CXB} 832^{\top}$ after incubation on ISP 2 with $10 \% \mathrm{NaCl}$ for 28 days at $37{ }^{\circ} \mathrm{C}$. Bars, $1 \mu \mathrm{m}$.

hydrolysate, wet biomass was well suspended in isopropanol/water $(1: 1, \mathrm{v} / \mathrm{v})$. For analysis of polar lipids and menaquinones, wet biomass was freeze-dried. Analysis of whole-cell sugars and amino acids in the cell-wall hydrolysate, polar lipids and menaquinones was carried out by the Identification Service of the DSMZ. Analysis of whole-cell sugars was performed according to the procedure described by Becker et al. (1965). Amino acids in the cell-wall hydrolysate were analysed by the method described by Schleifer \& Kandler (1972). Menaquinones were extracted and analysed according to Collins et al. (1979) and Groth et al. (1996). Polar lipids extracted by the method of Minnikin et al. (1979) were identified by two-dimensional TLC as described by Collins \& Jones (1980). The analysis of fatty acids was performed as described by Sasser (1990) and the results were compared with the database of fatty acids in the Microbial Identification System (MIDI) (TSBA6; version, 6.0B library). The whole-cell hydrolysates of strain CXB832 ${ }^{\mathrm{T}}$ contained meso-diaminopimelic acid as the diagnostic cell-wall peptidoglycan and the whole-cell sugars were glucose, xylose with traces of ribose and arabinose. Phospholipids (see Fig. S1 in IJSEM Online) comprised 
Table 1. Differentiating phenotypic and chemotaxonomic characteristics of strain CXB832 ${ }^{\top}$ and related genera of the family Nocardiopsaceae

Taxa: 1, strain CXB832 $;$; 2, Haloactinospora (data from this study and Tang et al., 2008); 3, Nocardiopsis (Hozzein \& Goodfellow, 2008); 4, Spinactinospora (Chang et al., 2011); 5, Marinactinospora (Tian et al., 2009); 6, Thermobifida (Yang et al., 2008); 7, Murinocardiopsis (Kämpfer et al., 2010); 8, Streptomonospora (Cai et al., 2008). Cell walls of all the taxa contain meso-diaminopimelic acid. Glu, glucose; Xyl, xylose; Rib, ribose; Gal, galactose; DPG, diphosphatidylglycerol; PC, phosphatidylcholine; PI, phosphatidylinositol; PG, phosphatidylglycerol; PIM, phosphatidylinositol mannoside; PME, phosphatidylmethylethanolamine; PL, phospholipids; GL, glycolipids; L1, unidentified lipids. NT, not tested; i, iso; ai, anteiso.

\begin{tabular}{|c|c|c|c|c|c|c|c|c|}
\hline Characteristic & 1 & 2 & 3 & 4 & 5 & 6 & 7 & 8 \\
\hline Isolation source & Salt pond & Salt lake & Sand dune soil & Marine sediment & Marine sediment & Salt mine & Indoor walls & Hypersaline soil \\
\hline Spore surface & Smooth & Smooth & Smooth & Spinous & Wrinkled & Smooth & No aerial mycelium & NT \\
\hline \multicolumn{9}{|l|}{ Growth conditions } \\
\hline $\mathrm{NaCl}$ range $(\%, \mathrm{w} / \mathrm{v})$ & $1-23$ & $9-21^{*}$ & $0-15$ & $1-15$ & $0-5$ & $0-10$ & $0-11$ & $5-20$ \\
\hline $\mathrm{NaCl}$ optimum $(\%, \mathrm{w} / \mathrm{v})$ & $9-12$ & $15^{*}$ & 5 & $3-8$ & $0-1$ & NT & NT & 10 \\
\hline Temperature range $\left({ }^{\circ} \mathrm{C}\right)$ & 37 & $37^{*}$ & $28-30$ & 37 & 28 & 45 & 28 & 37 \\
\hline Maximum temperature $\left({ }^{\circ} \mathrm{C}\right)$ & 50 & $45^{*}$ & 40 & 44 & 55 & 50 & 34 & 45 \\
\hline Diagnostic sugars & Glu, Xyl & Gal, Rib & Gal, Glu & Rib, Glu & None & Gal, Xyl, Glu & None & Gal \\
\hline Predominant menaquinones & $\begin{array}{c}\text { MK-10 }\left(\mathrm{H}_{2},\right. \\
\left.\mathrm{H}_{6}, \mathrm{H}_{8}\right) \\
\text { MK-9 }\left(\mathrm{H}_{8}\right)\end{array}$ & $\begin{array}{r}\text { MK-10 }\left(\mathrm{H}_{8}\right), \\
\text { MK-11( } \mathrm{H}_{4}, \\
\left.\mathrm{H}_{6}, \mathrm{H}_{8}\right)\end{array}$ & MK-10 $\left(\mathrm{H}_{4}, \mathrm{H}_{6}\right)$ & $\begin{array}{c}\text { MK-10 }\left(\mathrm{H}_{6}, \mathrm{H}_{8}\right), \\
\text { MK-9 }\left(\mathrm{H}_{8}\right)\end{array}$ & $\begin{array}{c}\text { MK-11 }\left(\mathrm{H}_{8}, \mathrm{H}_{10}\right) \\
\text { MK-10 }\left(\mathrm{H}_{8}\right)\end{array}$ & $\begin{array}{c}\text { MK- } \\
10\left(\mathrm{H}_{4}, \mathrm{H}_{6}, \mathrm{H}_{8}\right)\end{array}$ & $\begin{array}{c}\text { MK-10 }\left(\mathrm{H}_{4}, \mathrm{H}_{8}\right), \\
\left.\text { MK-11( } \mathrm{H}_{4}\right), \\
\left.\text { MK-12( } \mathrm{H}_{2}\right)\end{array}$ & $\begin{array}{c}\text { MK-10 }\left(\mathrm{H}_{8}, \mathrm{H}_{6}\right), \\
\quad \text { MK-11( }\left(\mathrm{H}_{8}\right)\end{array}$ \\
\hline Diagnostic phospholipids & $\begin{array}{c}\text { DPG, PG, PL, GL, } \\
\text { L1 }\end{array}$ & $\begin{array}{c}\text { DPG, PG, PC, } \\
\text { PIM }\end{array}$ & $\begin{array}{l}\text { PC, PME, DPG, } \\
\text { PG, PI, PIM, GL, } \\
\text { PL }\end{array}$ & $\begin{array}{c}\text { PG, PC, DPG, PI, } \\
\text { PL }\end{array}$ & $\begin{array}{c}\text { DPG, PC, PG, PIM, } \\
\text { PI, PL }\end{array}$ & $\begin{array}{l}\text { DPG, PME, PC, } \\
\text { PI, PG, PL }\end{array}$ & $\begin{array}{c}\text { PC, PG, PI, DPG, PL, } \\
\text { GL }\end{array}$ & $\begin{array}{c}\text { DPG, PG, PC, PIM, } \\
\text { PI, PL }\end{array}$ \\
\hline Major fatty acids $(>10 \%)$ & $\begin{array}{c}\mathrm{i}-\mathrm{C}_{16: 0}, \text { ai- } \mathrm{C}_{17: 0} \\
\mathrm{C}_{16: 0}\end{array}$ & ai- $C_{17: 0}, i-C_{16: 0} *$ & $\begin{array}{c}\mathrm{i}-\mathrm{C}_{16: 0}, 10- \\
\text { methyl- } \mathrm{C}_{18: 0} \text {, ai- } \\
\mathrm{C}_{17: 0}\end{array}$ & $\begin{array}{c}\mathrm{i}-\mathrm{C}_{16: 0}, \text { ai- } \mathrm{C}_{17: 0} \\
\mathrm{C}_{18: 0}\end{array}$ & $\begin{array}{r}\mathrm{i}-\mathrm{C}_{16: 0}, \mathrm{i}-\mathrm{C}_{16: 1} \mathrm{G} \\
10-\text { methyl- }_{18: 0}\end{array}$ & $\mathrm{i}-\mathrm{C}_{16: 0}$, ai- $\mathrm{C}_{17: 0}$ & $\begin{array}{c}\mathrm{i}-\mathrm{C}_{16: 0}, \text { ai }-\mathrm{C}_{17: 0}, \\
\mathrm{C}_{18: 1} \omega 9 c\end{array}$ & $\begin{array}{c}\mathrm{i}-\mathrm{C}_{16: 0}, \text { ai- } \mathrm{C}_{17: 0} \\
\text { 10-methyl- } \mathrm{C}_{18: 0} \\
\text { 10-methyl- } \mathrm{C}_{17: 0}\end{array}$ \\
\hline
\end{tabular}

${ }^{\star}$ Data from this study for Haloactinospora alba. This strain was grown under the same culture conditions as strain $\mathrm{CXB} 32^{\mathrm{T}}$. 
diphosphatidylglycerol, phosphatidylglycerol, phospholipids, glycolipid and unidentified lipids. The menaquinones consisted of MK-10 $\left(\mathrm{H}_{8}\right)(32 \%)$, MK-9 $\left(\mathrm{H}_{8}\right)$ (29\%), MK$10\left(\mathrm{H}_{2}\right)(20 \%)$, MK-10 $\left(\mathrm{H}_{6}\right)(17 \%)$ with traces of MK-6 $\left(\mathrm{H}_{6}\right)$ and $\mathrm{MK}-10\left(\mathrm{H}_{4}\right)$. The fatty acid profile contained $\mathrm{i}-\mathrm{C}_{16: 0}$ $(30.71 \%)$, ai- $\mathrm{C}_{17: 0} \quad(13.31 \%), \quad \mathrm{C}_{16: 0} \quad(11.82 \%), \quad \mathrm{C}_{18: 0}$ $(9.43 \%), \quad$ i-C $\mathrm{C}_{18: 0} \quad(6.56 \%), \quad 10$-methyl- $\mathrm{C}_{18: 0} \quad(6.08 \%)$, $\mathrm{C}_{18: 1} \omega 7 c$ and/or $\mathrm{C}_{18: 1} \omega 6 c$ (4.02\%), 10-methyl- $\mathrm{C}_{17: 0}$ (3.17\%), $\mathrm{C}_{16: 0} \quad 2-\mathrm{OH}(2.73 \%), \mathrm{i}-\mathrm{C}_{17: 0}(2.63 \%), \mathrm{C}_{17: 0}$ $(2.63 \%), \quad \mathrm{C}_{18: 1} \omega 9 c \quad(2.52 \%), \quad$ ai- $\mathrm{C}_{15: 0} \quad(1.47 \%), \quad \mathrm{C}_{14: 0}$ $(1.19 \%), \mathrm{C}_{17: 0}$ iso $\omega 9 c$ and/or 10 -methyl- $\mathrm{C}_{16: 0}(1.14 \%)$ and $\mathrm{i}-\mathrm{C}_{14: 0}(0.56 \%)$.

The $\mathrm{G}+\mathrm{C}$ content of the chromosomal DNA was determined according to the methods described by Mesbah et al. (1989) using reverse-phase HPLC. The $\mathrm{G}+\mathrm{C}$ content of strain $\mathrm{CXB} 832^{\mathrm{T}}$ was $60.1 \mathrm{~mol} \%$.

Genomic DNA extraction and PCR amplification of the $16 \mathrm{~S}$ rRNA gene were conducted as described by Li et al. (2007). The 16S rRNA gene sequence was aligned and compared with available sequences in the GenBank/EMBL/DDBJ database using BLAST searches. The identification of phylogenetic neighbours and the calculation of pairwise $16 \mathrm{~S}$ rRNA gene sequence similarities were achieved using the EzTaxon server (http://www.eztaxon.org/; Chun et al., 2007). Sequences were aligned using CLUSTAL_X 1.8 (Thompson et al., 1997) (the sequence alignment is available as supplementary material in IJSEM Online). The phylogenetic trees were constructed using the neighbour-joining and maximum-likelihood methods with Kimura 2-state parameter model analyses implemented in the MEGA version 5 program (Tamura et al., 2007). In each case, bootstrap values were calculated based on 1000 replicates.

BLAST results for the 16S rRNA gene sequence of strain $\mathrm{CXB832}{ }^{\mathrm{T}}$ showed that its closest relatives were members of genera Nocardiopsis and Haloactinospora in the family Nocardiopsaceae, with the highest gene sequence similarity of $95.4 \%$ with Nocardiopsis arabia DSM $45083^{\mathrm{T}}$ and $94.9 \%$ with Haloactinospora alba DSM $45015^{\mathrm{T}}$, respectively. In the neighbour-joining (Fig. 2) and maximum-likelihood trees (Fig. S2) based on the 16S rRNA gene sequences of representatives of all genera in family Nocardiopsaceae, strain $\mathrm{CXB} 832^{\mathrm{T}}$ formed a distinct lineage, which showed the evolutionary divergence between strain $\mathrm{CXB} 832^{\mathrm{T}}$ and the previously described genera in this family.

The phenotypic and chemotaxonomic characteristics of the novel strain could be readily distinguished from the closest

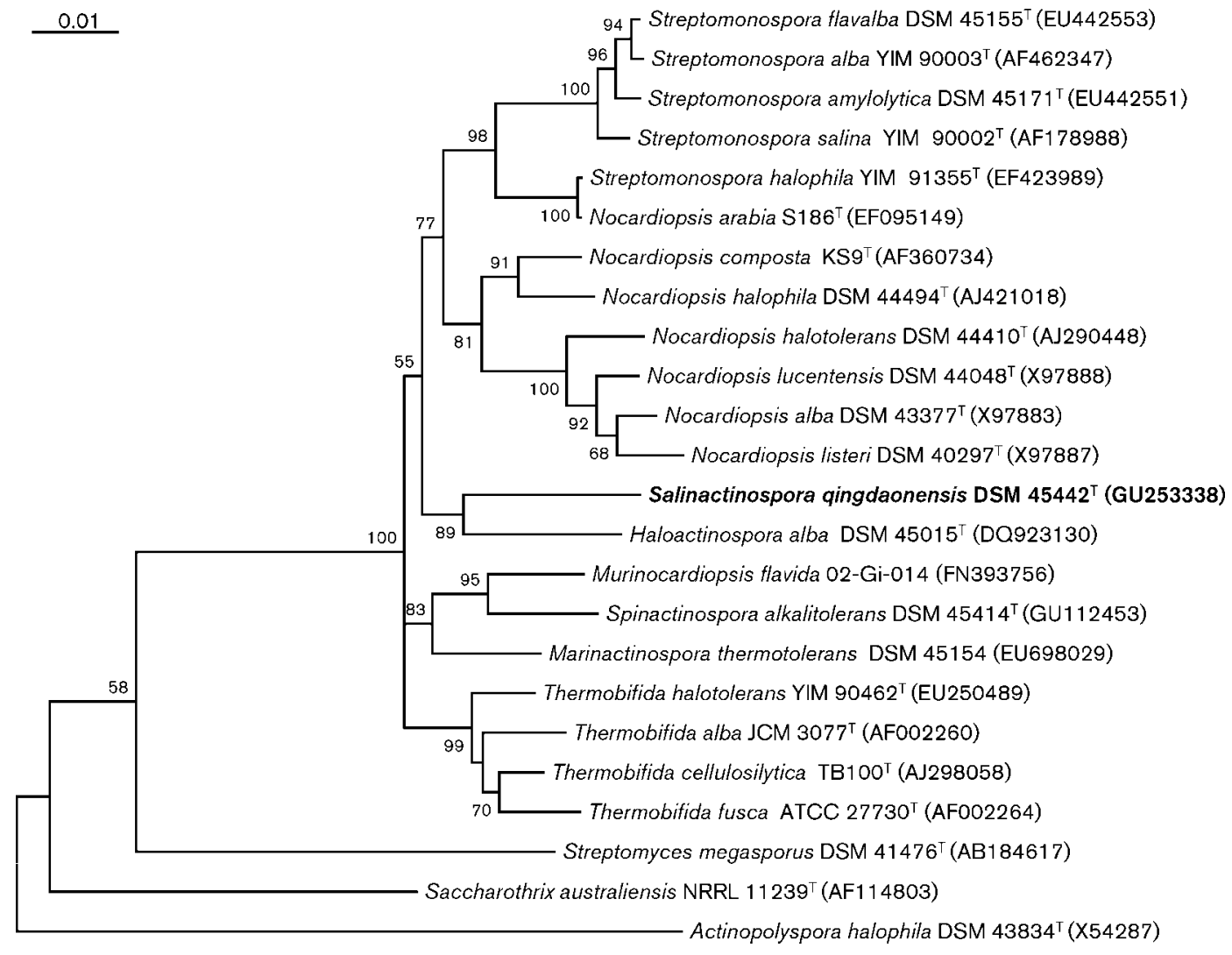

Fig. 2. Phylogenetic dendrogram obtained by neighbour-joining analysis based on $16 \mathrm{~S}$ rRNA gene sequences showing the position of strain $\mathrm{CXB} 832^{\top}$ and its phylogenetic neighbours. Numbers at nodes are bootstrap values based on 1000 resamplings (only values $>50 \%$ are indicated). Bar, $1 \%$ sequence divergence. 
phylogenetic genera, Nocardiopsis and Haloactinospora, by the maximum $\mathrm{NaCl}$ concentration for growth, the diagnostic sugars, the predominant menaquinones and the diagnostic phospholipids. The maximum $\mathrm{NaCl}$ concentration for growth of strain CXB832 $2^{\mathrm{T}}$ was $23 \%(\mathrm{w} / \mathrm{v})$, but members of the genera Nocardiopsis and Haloactinospora are unable to grow at this concentration. The diagnostic sugars of strain $\mathrm{CXB} 832^{\mathrm{T}}$ were glucose and xylose, which are different from those found for the other two genera. The predominant menaquinones for strain $\mathrm{CXB} 832^{\mathrm{T}}$ were MK$10\left(\mathrm{H}_{2}, \mathrm{H}_{6}, \mathrm{H}_{8}\right)$ and MK-9 $\left(\mathrm{H}_{8}\right)$, but MK-10 $\left(\mathrm{H}_{2}\right)$ and MK$9\left(\mathrm{H}_{8}\right)$ are absent from members of the genera Nocardiopsis and Haloactinospora. The diagnostic phospholipids of the genera Nocardiopsis and Haloactinospora are phosphatidylcholine (PC), phosphatidylinositol (PI), phosphatidylinositol mannoside (PIM) and phosphatidylmethylethanolamine (PME), but none of these phospholipids were present in strain $\mathrm{CXB} 832^{\mathrm{T}}$. Other characteristics that differentiated strain $\mathrm{CXB} 832^{\mathrm{T}}$ from members of the other seven genera of the family Nocardiopsaceae are shown in Table 1. Thus, based on the above phenotypic and genotypic results, strain $\mathrm{CXB832}{ }^{\mathrm{T}}$ represents a novel genus for which the name Salinactinospora gen. nov. is proposed. The type species of the genus is Salinactinospora qingdaonensis sp. nov.

\section{Description of Salinactinospora gen. nov.}

Salinactinospora (Sa.lin.ac.ti.no'spo.ra. N.L. adj. salinus saline; Gr. n. actis actinos a ray; Gr. n. spora a seed; N.L. fem. $n$. Salinactinospora an actinomycete originating from a saline habitat).

Gram-positive-staining, aerobic, moderately halophilic, filamentous actinomycetes. The aerial mycelium forms long chains of spores. Spores are rod-shaped with smooth surfaces. Substrate mycelium is extensively branched with non-fragmenting hyphae. No diffusible pigments are produced. The whole-cell hydrolysates contain mesodiaminopimelic acid, glucose and xylose. The predominant menaquinones are MK-10 $\left(\mathrm{H}_{2}\right)$, MK- $10\left(\mathrm{H}_{6}\right)$, MK- $10\left(\mathrm{H}_{8}\right)$ and MK-9 $\left(\mathrm{H}_{8}\right)$. The phospholipids are diphosphatidylglycerol, phosphatidylglycerol, phospholipids, glycolipid and unidentified lipids. The major fatty acids are $\mathrm{i}-\mathrm{C}_{16: 0}$, ai- $\mathrm{C}_{17: 0}$ and $\mathrm{C}_{16: 0}$. The $\mathrm{G}+\mathrm{C}$ content of the genomic DNA is $60.1 \mathrm{~mol} \%$.

\section{Description of Salinactinospora qingdaonensis sp. nov.}

Salinactinospora qingdaonensis (qing.da.o.nen'sis. N.L. fem. adj. qingdaonensis pertaining to Qingdao, a city in the coastal region of East China, from which the type strain was isolated).

Displays the following properties in addition to those described for the genus. Good growth on ISP 2, ISP 3, ISP 4 and ISP 5 agars, Czapek solution agar, nutrient agar and potato agar supplemented with $10 \%(\mathrm{w} / \mathrm{v}) \mathrm{NaCl}$. The colour of the aerial mycelium is white and the substrate mycelium is pale yellow to deep yellow on ISP 4 agars supplemented with $10 \%(\mathrm{w} / \mathrm{v}) \mathrm{NaCl}$. Growth occurs between 16 and $50{ }^{\circ} \mathrm{C}$, but not at 4 or $51{ }^{\circ} \mathrm{C}$. Grows at $\mathrm{pH}$ 6.0-9.0 and with 1-23\%(w/v) $\mathrm{NaCl}$, with optimum growth at $\mathrm{pH} 7.0-8.0$ and $37{ }^{\circ} \mathrm{C}$ with $9-12 \%(\mathrm{w} / \mathrm{v}) \mathrm{NaCl}$. Utilizes $\alpha$-cyclodextrin, dextrin, glycogen, inulin, mannan, L-arabinose, D-arabitol, arbutin, cellobiose, D-galactose, Dglucose, lactose, lactulose, maltose, maltotriose, D-mannose, melibiose, raffinose, L-rhamnose, sucrose, salicin, D-ribose, D-sorbitol, turanose, xylitol and inosine as sole carbon sources, but D-fructose, L-fucose, inositol, Dgalacturonic acid, D-mannitol, melezitose, stachyose, Dxylose, D-tagatose and D-psicose are not utilized. Susceptible to ( $\mu$ g per disc): norfloxacin (10), vancomycin (30), amoxicillin (10), minocycline (30) and erythromycin (15). Resistant to ( $\mu \mathrm{g}$ per disc): penicillin (10), oxacillin (1), ampicillin (10), carbenicillin (100), amikacin (30), gentamicin (10), kanamycin (30), neomycin (30), midecamycin (30), ofloxacin (5), norfloxacin (10), polymyxin B (300), furazolidone (300), clindamycin (2), netilmicin (30), ciprofloxacin (5), tobramycin (10), trimethoprim (5), lincomycin (2) and streptomycin (10). Tests for hydrolysis of starch and cellulose, melanin production, $\mathrm{H}_{2} \mathrm{~S}$ production and gelatin liquefaction are negative, whereas tests for Tweens 20, 40, 60 and 80 , nitrate reduction, utilization of urea, milk coagulation and milk peptonization are positive. The fatty acid profile contained mainly $\mathrm{i}-\mathrm{C}_{16: 0}$, ai- $\mathrm{C}_{17: 0}$ and $\mathrm{C}_{16: 0}$.

The type strain, CXB832 ${ }^{\mathrm{T}}\left(=\mathrm{DSM} 45442^{\mathrm{T}}=\mathrm{LMG} 25567^{\mathrm{T}}\right)$, was isolated from a salt pond in Qingdao, China. The DNA $\mathrm{G}+\mathrm{C}$ content of the type strain is $60.1 \mathrm{~mol} \%$.

\section{Acknowledgements}

This work was supported by a grant from the National High Technology Research and Development Program of China (863 Program, No. 2007AA09Z434) and a grant from the National Natural Science Foundation of China (No. 40876067).

\section{References}

Becker, B., Lechevalier, M. P. \& Lechevalier, H. A. (1965). Chemical composition of cell-wall preparations from strains of various formgenera of aerobic actinomycetes. Appl Microbiol 13, 236-243.

Cai, M., Zhi, X.-Y., Tang, S.-K., Zhang, Y.-Q., Xu, L.-H. \& Li, W.-J. (2008). Streptomonospora halophila sp. nov., a halophilic actinomycete isolated from a hypersaline soil. Int J Syst Evol Microbiol 58, 1556-1560.

Cai, M., Tang, S.-K., Chen, Y. G., Li, Y., Zhang, Y.-O. \& Li, W.-J. (2009). Streptomonospora amylolytica sp. nov. and Streptomonospora flavalba sp. nov., two novel halophilic actinomycetes isolated from a salt lake. Int J Syst Evol Microbiol 59, 2471-2475.

Chang, X. B., Liu, W. Z. \& Zhang, X.-H. (2011). Spinactinospora alkalitolerans gen. nov., sp. nov., an actinomycete isolated from marine sediment. Int J Syst Evol Microbiol 61, 2805-2810.

Chen, Y.-G., Cui, X.-L., Kroppenstedt, R. M., Stackebrandt, E., Wen, M.-L., Xu, L.-H. \& Jiang, C.-L. (2008). Nocardiopsis quinghaiensis sp. nov., isolated from saline soil in China. Int J Syst Evol Microbiol 58, 699-705. 
Chun, J., Lee, J.-H., Jung, Y., Kim, M., Kim, S., Kim, B. K. \& Lim, Y. W. (2007). EzTaxon: a web-based tool for the identification of prokaryotes based on $16 \mathrm{~S}$ ribosomal RNA gene sequences. Int J Syst Evol Microbiol 57, 2259-2261.

Collins, M. D. \& Jones, D. (1980). Lipids in the classification and identification of coryneform bacteria containing peptidoglycans based on 2,4-diaminobutyric acid. J Appl Bacteriol 48, 459-470.

Collins, M. D., Goodfellow, M. \& Minnikin, D. E. (1979). Isoprenoid quinones in the classification of coryneform and related bacteria. J Gen Microbiol 110, 127-136.

Cui, X. L., Mao, P. H., Zeng, M., Li, W. J., Zhang, L. P., Xu, L. H. \& Jiang, C. L. (2001). Streptimonospora salina gen. nov., sp. nov., a new member of the family Nocardiopsaceae. Int J Syst Evol Microbiol 51, 357-363.

Gonzalez, C., Gutierrez, C. \& Ramirez, C. (1978). Halobacterium vallismortis sp. nov. An amylolytic and carbohydrate-metabolizing, extremely halophilic bacterium. Can J Microbiol 24, 710-715.

Groth, I., Schumann, P., Weiss, N., Martin, K. \& Rainey, F. A. (1996). Agrococcus jenensis gen. nov., sp. nov., a new genus of actinomycetes with diaminobutyric acid in the cell wall. Int J Syst Bacteriol 46, 234 239.

Groth, I., Rodríguez, C., Schütze, B., Schmitz, P., Leistner, E. \& Goodfellow, M. (2004). Five novel Kitasatospora species from soil: Kitasatospora arboriphila sp. nov., $K$. gansuensis sp. nov., $K$. nipponensis sp. nov., $K$. paranensis sp. nov. and $K$. terrestris sp. nov. Int J Syst Evol Microbiol 54, 2121-2129.

Hozzein, W. N. \& Goodfellow, M. (2008). Nocardiopsis arabia sp. nov., a halotolerant actinomycete isolated from a sand-dune soil. Int J Syst Evol Microbiol 58, 2520-2524.

Kämpfer, P., Busse, H. J. \& Rainey, F. A. (2002). Nocardiopsis compostus sp. nov., from the atmosphere of a composting facility. Int J Syst Evol Microbiol 52, 621-627.

Kämpfer, P., Schäfer, J., Lodders, N. \& Martin, K. (2010). Murinocardiopsis flavida gen. nov., sp. nov., an actinomycete isolated from indoor walls. Int J Syst Evol Microbiol 60, 1729-1734.

Kelly, K. L. (1964). Inter-Society Color Council - National Bureau of Standards Color Name Charts Illustrated with Centroid Colors. Washington, DC: US Government Printing Office.

Kroppenstedt, R. M. \& Evtushenko, L. I. (2006). The family Nocardiopsaceae. In The Prokaryotes: A Handbook on the Biology of Bacteria, 3rd edn, vol. 3, pp. 754-795. Edited by M. Dworkin, S. Falkow, E. Rosenberg, K. H. Schleifer \& E. Stackebrandt. New York: Springer-Verlag.

Kukolya, J., Nagy, I., Láday, M., Tóth, E., Oravecz, O., Márialigeti, K. \& Hornok, L. (2002). Thermobifida cellulolytica sp. nov., a novel lignocellulose-decomposing actinomycete. Int J Syst Evol Microbiol 52, 1193-1199.

Li, M.-G., Li, W.-J., Xu, P., Cui, X.-L., Xu, L.-H. \& Jiang, C.-L. (2003). Nocardiopsis xinjiangensis sp. nov., a halophilic actinomycete isolated from a saline soil sample in China. Int J Syst Evol Microbiol 53, 317-321.

Li, W.-J., Xu, P., Zhang, L.-P., Tang, S.-K., Cui, X.-L., Mao, P.-H., Xu, L.-H., Schumann, P., Stackebrandt, E. \& Jiang, C. L. (2003). Streptomonospora alba sp. nov., a novel halophilic actinomycete, and emended description of the genus Streptomonospora Cui et al. 2001. Int J Syst Evol Microbiol 53, 1421-1425.

Li, W.-J., Park, D.-J., Tang, S.-K., Wang, D., Lee, J.-C., Xu, L.-H., Kim, C.-J. \& Jiang, C.-L. (2004). Nocardiopsis salina sp. nov., a novel halophilic actinomycete isolated from saline soil in China. Int J Syst Evol Microbiol 54, 1805-1809.

Li, W.-J., Kroppenstedt, R. M., Wang, D., Tang, S.-K., Lee, J.-C., Park, D.-J., Kim, C.-J., Xu, L.-H. \& Jiang, C.-L. (2006). Five novel species of the genus Nocardiopsis isolated from hypersaline soils and emended description of Nocardiopsis salina Li et al. 2004. Int J Syst Evol Microbiol 56, 1089-1096.

Li, W.-J., Xu, P., Schumann, P., Zhang, Y. Q., Pukall, R., Xu, L. H., Stackebrandt, E. \& Jiang, C. L. (2007). Georgenia ruanii sp. nov., a novel actinobacterium isolated from forest soil in Yunnan (China), and emended description of the genus Georgenia. Int J Syst Evol Microbiol 57, 1424-1428.

Mesbah, M., Premachandran, U. \& Whitman, W. B. (1989). Precise measurement of the $\mathrm{G}+\mathrm{C}$ content of deoxyribonucleic acid by high performance liquid chromatography. Int J Syst Evol Microbiol 39, $159-167$.

Meyer, J. (1976). Nocardiopsis, a new genus of the order Actinomycetales. Int J Syst Bacteriol 26, 487-493.

Minnikin, D. E., Collins, M. D. \& Goodfellow, M. (1979). Fatty acid and polar lipid composition in the classification of Cellulomonas, Oerskovia and related taxa. J Appl Bacteriol 47, 87-95.

Rainey, F. A., Ward-Rainey, N., Kroppenstedt, R. M. \& Stackebrandt, E. (1996). The genus Nocardiopsis represents a phylogenetically coherent taxon and a distinct actinomycete lineage: proposal of Nocardiopsaceae fam. nov. Int J Syst Bacteriol 46, 1088-1092.

Sabry, S. A., Ghanem, N. B., Abu-Ella, G. A., Schumann, P., Stackebrandt, E. \& Kroppenstedt, R. M. (2004). Nocardiopsis aegyptia sp. nov., isolated from marine sediment. Int J Syst Evol Microbiol 54, 453-456.

Sasser, M. (1990). Identification of bacteria by gas chromatography of cellular fatty acids. USFCC Newsl 20, 16.

Schleifer, K. H. \& Kandler, O. (1972). Peptidoglycan types of bacterial cell walls and their taxonomic implications. Bacteriol Rev 36, 407-477.

Shirling, E. B. \& Gottlieb, D. (1966). Methods for characterization of Streptomyces species. Int J Syst Bacteriol 16, 313-340.

Tamura, K., Dudley, J., Nei, M. \& Kumar, S. (2007). MEGA4: molecular evolutionary genetics analysis (MEGA) software version 4.0. Mol Biol Evol 24, 1596-1599.

Tang, S.-K., Tian, X.-P., Zhi, X.-Y., Cai, M., Wu, J.-Y., Yang, L.-L., Xu, L.-H. \& Li, W.-J. (2008). Haloactinospora alba gen. nov., sp. nov., a halophilic filamentous actinomycete of the family Nocardiopsaceae. Int J Syst Evol Microbiol 58, 2075-2080.

Thompson, J. D., Gibson, T. J., Plewniak, F., Jeanmougin, F. \& Higgins, D. G. (1997). The CLUSTAL_X windows interface: flexible strategies for multiple sequence alignment aided by quality analysis tools. Nucleic Acids Res 25, 4876-4882.

Tian, X.-P., Tang, S.-K., Dong, J.-D., Zhang, Y.-Q., Xu, L.-H., Zhang, S. \& Li, W.-J. (2009). Marinactinospora thermotolerans gen. nov., sp. nov., a marine actinomycete isolated from a sediment in the northern South China Sea. Int J Syst Evol Microbiol 59, 948-952.

Waksman, S. A. (1961). Classification, Identification and Description of Genera and Species, vol. II. The Actinomycetes. Baltimore: Williams \& Wilkins.

Xu, P., Li, W.-J., Tang, S.-K., Zhang, Y.-Q., Chen, G.-Z., Chen, H.-H., Xu, L.-H. \& Jiang, C.-L. (2005). Naxibacter alkalitolerans gen. nov., sp. nov., a novel member of the family 'Oxalobacteraceae' isolated from China. Int J Syst Evol Microbiol 55, 1149-1153.

Yang, R.-L., Zhang, L.-P., Guo, L.-G., Shi, N., Lu, Z.-T. \& Zhang, X.-M. (2008). Nocardiopsis valliformis sp. nov., an alkaliphilic actinomycete isolated from alkali lake soil in China. Int J Syst Evol Microbiol 58, 1542-1546.

Zhang, Z., Wang, Y. \& Ruan, J. (1998). Reclassification of Thermomonospora and Microtetraspora. Int J Syst Bacteriol 48, 411422. 